\title{
Note
}

\section{Photosynthesis and Transpiration of an Emergent Plant Zizania latifolia}

\author{
Takayoshi Tsuchiya, Atsushi ShInozuka and Isao Ikusima
}

\begin{abstract}
Photosynthesis and transpiration were measured for a stand of the emergent plant, Zizania latifolia (GRISEB.) TuRCz. at a sheltered shore of the Hitachi-Tone River, Japan. Net photosynthetic rate per unit leaf area at light saturation was $12 \mu \mathrm{mol} \mathrm{CO} \cdot \mathrm{m}^{-2}$. $\mathrm{s}^{-1}$, which is in the lower range for emergent plants. The daily course of net photosynthesis and transpiration had no midday depression, $i$. $e$. the maximum was recorded around noon. Vapor pressure difference did not regulate leaf conductance at photosynthetic photon flux densities saturating net photosynthesis.
\end{abstract}

Key Words : emergent plant, photosynthesis, transpiration, Zizania latifolia

\section{Introduction}

The emergent vegetation is one of the sites showing the highest primary production in the world (WestLake, 1982). We reported a high productivity of Zizania latifolia (GRISEB.) TuRcz. along the shore of the Hitachi-Tone River, Japan (Tsuchrya et al., 1993) with its large allocation of biomass production to foliage structure.

High resource availability may also have allowed high productivity. Carbon availability from the air is higher of several magnitudes than from water (MADSEN and SAND-JENSEN, 1991). Having aerial leaves as well as terrestrial plants is highly advantageous to carbon uptake. In comparison with carbon, however, water tends to be less available to aerial leaves. IshiHARA and SAITOH (1987) reported that stomatal closure associated with midday depression of photosynthesis was partly due to water deficiency, even for Oryza sativa L. grown under irrigation. Midday depression was also reported for some wild emergent plants (PeArcy et al., 1974 ; Sale et al., 1985 ; Sale and ORR, 1986), though it was related to increased leaf temperature. In contrast, JonEs (1987) re- ported that a $\mathrm{C}_{4}$ emergent plant, Cyperus papyrus L. did not show midday depression in spite of the presence of stomatal regulation dependent on the vapor pressure difference between the intercellular spaces in the leaf and the atmosphere (VPD). Diurnal change in leaf conductance as it relates to photosynthesis and transpiration is still unknown for many other emergent plants.

$Z$. latifolia is closely related to $O$. sativa, both of which develop a relatively poor root system in muddy sediments compared with their thick foliage above the water surface. The objectives of the present study are (1) to measure diurnal change in the photosynthesis and transpiration of $Z$. latifolia and (2) to clarify whether its stomata are closed at midday.

\section{Materials and methods}

The study site is located on a relatively sheltered shore of the Hitachi-Tone River near its confluence with the Tone River. Emergent vegetation extends along the shore to a width of about $10 \mathrm{~m}$ and a water depth of $1 \mathrm{~m}$. The vegetation is dominated by $Z$. latifolia with a low coverage of Phragmites australis (CAv.) Trin. ex. Steudel. Further details of the study 
site were described previously (Tsuchiya et al., 1993).

Z. Latifolia has stomata on both abaxial and adaxial sides of the leaf lamina. Gas exchange was measured using a portable porometer with a chamber for leaves having stomata on both abaxial and adaxial sides (Koito KIP-8501, Yokohama, Japan). Leaf temperature, air temperature and photosynthetic photon flux density (PFD) were obtained simultaneously. Net photosynthesis, transpiration, leaf conductance and VPD were obtained according to IsHIKAWA et al. (1990).

In a preliminary study we found that net photosynthesis and transpiration did not differ significantly based on location within a leaf lamina, which usually reaches a length of more than $1 \mathrm{~m}$. In contrast, leaf age affected photosynthesis. We measured the highest net photosynthesis on the second to fourth youngest leaves out of a total of six leaves per a shoot, whereas transpiration was not significantly different except for the oldest leaves which showed higher rates and greater leaf conductance.

In order to eliminate the factor of leaf age, therefore, we selected 12 leaves of the second to fourth leaf orders out of 4 shoots within a $1 \mathrm{~m} \times$ $1 \mathrm{~m}$ quadrat at the center of the $Z$. latifolia stand. Diurnal changes in photosynthesis and transpiration were measured hourly from $9: 00$ to 18:00 (solar time) on 3 August 1990, one of the hottest and driest days of the year. For the 8 to 12 leaves selected, the assimilation chamber was placed at the center or somewhat higher where the surface inclination was nearly horizontal.

\section{Results}

On the measurement day there were few clouds in the sky except between $9: 30$ and 10 : 30 a.m. Maximum PFD above the leaf canopy was about $2 \mathrm{mmol} \cdot \mathrm{m}^{-2} \cdot \mathrm{s}^{-1}$ at noon. Since our random selection also included leaves shaded by other overlying leaves, the PFDs measured on the leaf surface varied widely from 10 to $100 \%$ of full sunlight (Fig. 1A). Air temperature varied from 29 to $35^{\circ} \mathrm{C}$ during the day, its peak being later than that of PFD and VPD (Fig. 1B). Leaf temperature of $Z$. latifolia did not exceed air temperature by more than $1^{\circ} \mathrm{C}$, indicating that an unrestrained transpiration rate from the lamina surface cooled the leaf. VPD in the ambient air was about $15 \mathrm{mmol}$. $\mathrm{mol}^{-1}$ at midday (Fig. 1C).

Daily changes in photosynthetic rate coincided roughly with those in PFD and VPD. Maximum net photosynthesis was on a high plateau, $10-14 \mu \mathrm{mol} \mathrm{CO}{ }_{2} \cdot \mathrm{m}^{-2} \cdot \mathrm{s}^{-1}$, from $11: 00$ till 16:00 (Fig. 1D) because of the saturating PFDs. Relationship of PFD and net photosynthesis did not differ from morning to afternoon (Fig. 2A). Maximum rates of transpiration and leaf conductance occurred slightly later than those of photosynthesis (Fig. 1). Maximum transpiration was $3 \mathrm{mmol} \mathrm{H}_{2} \mathrm{O} \cdot \mathrm{m}^{-2} \cdot \mathrm{s}^{-1}$ when leaf conductance was about $0.25 \mu \mathrm{mol} \mathrm{H}_{2} \mathrm{O}$. $\mathrm{m}^{-2} \cdot \mathrm{s}^{-1}$. Transpiration tended to be saturated by higher PFD in the afternoon than in the morning (Fig. 2B), presumably because of higher VPD. Midday depression of photosynthesis and transpiration was not observed.

Leaf conductance was dependent on PFD and their relation also did not differ from morning to afternoon (Fig. 3A). Values of leaf conductance obtained at above light saturation (about 1 $\mathrm{mmol} \cdot \mathrm{m}^{-2} \cdot \mathrm{s}^{-1}$ in PFD) were plotted against the prevailing VPD in order to eliminate the effect of PFD on leaf conductance (Fig. 3B) In contrast to PFD, VPD did not affect leaf conductance in a surplus of PFD.

\section{Discussion}

Water use efficiency, calculated as photosynthesis divided by transpiration, of $Z$. latifolia was only about $3 \mathrm{mmol} \mathrm{CO} \cdot \mathrm{mol}^{-1} \mathrm{H}_{2} \mathrm{O}$ relatively constant during midday. This value is similar to that of a $\mathrm{C}_{3}$ emergent plant, Typha latifolia $\mathrm{L}$., $\left(2.8-4.9 \mathrm{mmol} \cdot \mathrm{mol}^{-1}\right.$, MCNAuGHTON, 1973), and lower than a $\mathrm{C}_{4}$ emergent plant, Cyperus papyrus $\left(6.5 \mathrm{mmol} \cdot \mathrm{mol}^{-1}\right.$, Jones, 1987) or terrestrial plants ( 5 to $8 \mathrm{mmol} \cdot \mathrm{mol}^{-1}$, Yoshie, 1986), Therefore, in addition to its relatively low net photosynthetic rate, $Z$. latifolia must be considered a $\mathrm{C}_{3}$ plant, though there have been no anatomical or physiological reports to verify 

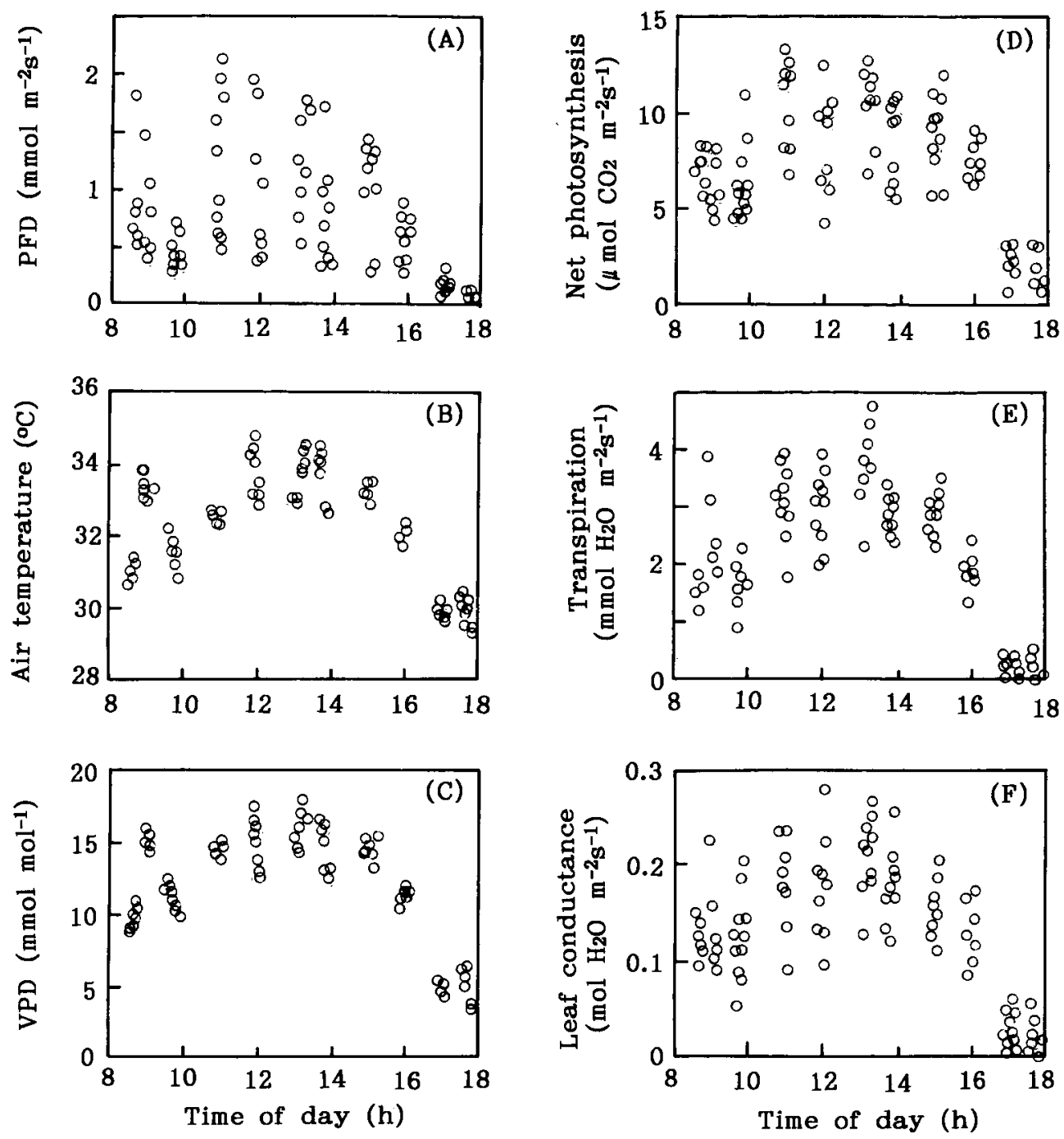

Fig. 1. Diurnal changes in (A) PFD on leaf surface, (B) air temperature, (C) ambient air VPD, (D) net photosynthetic rate, $(\mathrm{E})$ transpiration rate, and $(\mathrm{F})$ leaf conductance of $Z$. latifolia leaves. Measured on 3 August 1990.
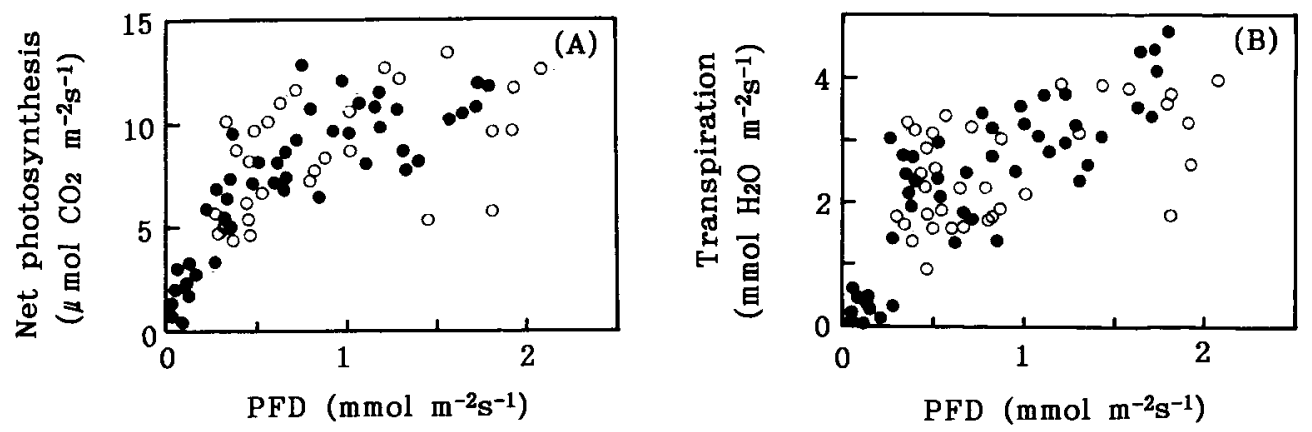

Fig. 2. PFD dependence of (A) net photosynthesis and (B) transpiration of $Z$. latifolia in the morning (open circles) and afternoon (solid circles). Data are the same as in Fig. 1. 

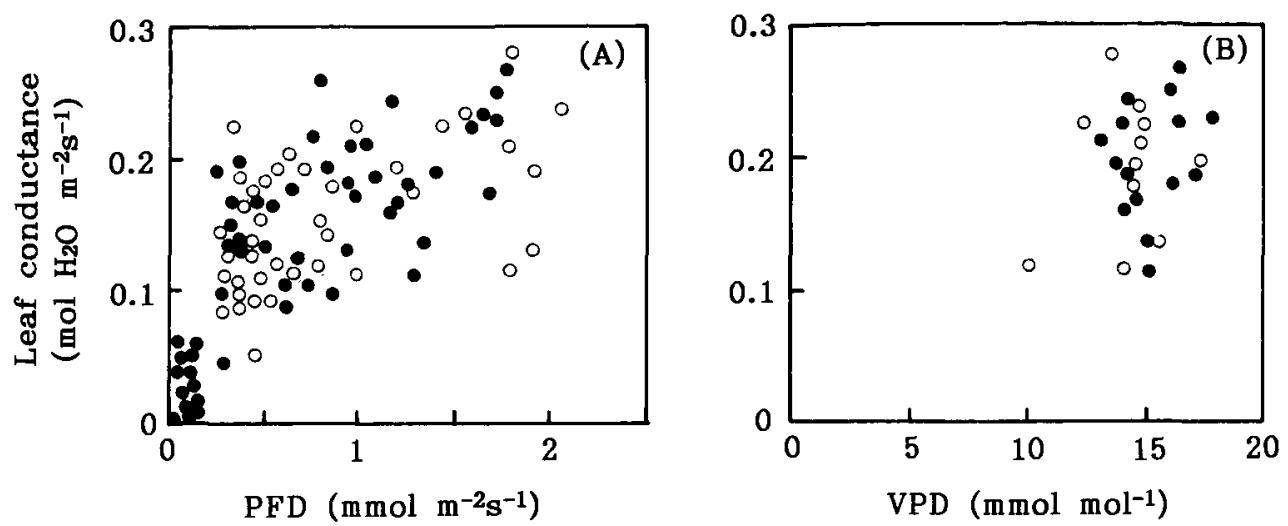

Fig. 3. Leaf conductance of $Z$. latifolia in relation to (A) PFD and (B) VPD. Data at PFDs higher than $1 \mathrm{mmol} \cdot \mathrm{m}^{-2} \cdot \mathrm{s}^{-1}$ are shown in the right figure. Symbols are the same as in Fig. 2 .

this. Lower water use efficiency is not an adaptive disadvantage for aquatic plants insofar as water deficiency does not occur in their leaves. High transpiration results in a lowering of leaf temperature which reduces respiration, thus maintaining high net photosynthesis (PEAR. CY et al., 1974).

While a $\mathrm{C}_{4}$ emergent plant, $C$. papyrus was reported having an extremely high photosynthetic rate of up to $35 \mu \mathrm{mol} \cdot \mathrm{m}^{-2} \cdot \mathrm{s}^{-1}$ (JONES, 1987), $C_{3}$ emergent plants have maximum net photosynthetic rates ranging from 10 to $25 \mu \mathrm{mol} \cdot \mathrm{m}^{-2} \cdot \mathrm{s}^{-1}$ (PEARCy et al., 1974; Gloser, 1977 ; SPENCER and Bowes, 1986; IshIHARA and SaItoh, 1987 ; Jones, 1988). The maximum net photosynthesis of $Z$. latifolia in the present study falls in the lower range. However, its annual net production is more than $3400 \mathrm{~g}$ dry weight $\cdot \mathrm{m}^{-2}$ (Tsuchiy a et al., 1993), which is the higher range for herbaceous plants in temperate zone (LARCHER, 1984). This may be due to its dense foliage with relatively vertical leaf orientation, which keeps light penetration through the foliage onto the ground surface to only 1\% (Tsuchya et al., unpublished data). The leaf area index reached $6.0 \mathrm{~m}^{2} \cdot \mathrm{m}^{-2}$ in August (Tsuchiya et al., 1993), close to the mean of values reported for emergent plants (Tsuchiya, 1991). The relatively low photosynthetic activity may be compensated for by its thick foliage structure with inclined lamina orientations.

Midday depression of photosynthesis occurs in many terrestrial plants, presumably owing to a decrease in $\mathrm{CO}_{2}$ concentration, an accumulation of photosynthetate, and a higher afternoon temperature (Tenhunen et al., 1984 ; RoEssLeR and Monson, 1985). Similar findings have also been reported for several emergent plants; IshiHARA and SAITOH (1987) observed a midday depression with an increase in VPD and a decrease in water potential in a cultivated plant, $O$. sativa, when maximum VPD was about $30 \mathrm{mmol} \cdot \mathrm{mol}^{-1}$. This species has a higher leaf conductance $\left(0.69 \mathrm{~mol} \cdot \mathrm{m}^{-2} \cdot \mathrm{s}^{-1}\right)$ than uncultivated aquatic plants $(0.17-0.35 \mathrm{~mol}$. $\mathrm{m}^{-2} \cdot \mathrm{s}^{-1}$ ) (PeArcy et al., 1974 ; GLOSER, 1977; KÖRNER et al., 1979 ; SPENCER and Bowes, 1986). This indicates that water deficiency in leaves is more likely to occur in $O$. sativa than in wild aquatic plants. $P$. australis was also reported to show midday depression, owing not to water stress but primarily to high temperature in the afternoon (PEARCY et al., 1974; ONDOK and Gloser, 1978). C. papyrus showed no midday depression of photosynthesis in spite of VPD dependence of stomatal conductance (JonES, 1987). Z. latifolia in the present study showed no midday depression. Moreover, its stomata responded little to a change in VPD ranging from 10 to $20 \mathrm{mmol} \cdot \mathrm{mol}^{-1}$, the same range in which $O$. sativa showed a significant decrease in 
net photosynthesis with increasing VPD (ISHIHARA and KUROIDA, 1986). The high productivity of $Z$. latifolia may be partly due to its high water availability together with its well-developed foliage structure.

\section{Acknowledgments}

This study was partly supported by a grant from the Nihon Seimei Foundation.

摘要

\section{抽水植物マコモの光合成および蒸散特性}

常陸利根川の河岸のマコモ個体群において光合 成速度と蒸散速度の日変化を測定した。最大純光 合成速度は約 $12 \mu \mathrm{mol} \mathrm{CO} \cdot \mathrm{m}^{-2} \cdot \mathrm{s}^{-1}$ であり, 抽水 植物の值としては低い方であった。光合成速度と 蒸散速度はともに真昼に最大值をとり，昼寝現象 はみられなかった。光強度が光合成や蒸散を律速 しており，大気一葉内飽差は葉コンダクタンスの 制限要因とはならなかった。

\section{References}

Gloser, J. (1977): Characteristics of $\mathrm{CO}_{2}$ exchange in Phragmites communis TRIN. derived from measurements in situ. Photosynthetica, 11: 139-147.

Ishimara, K. and E. Kuroda (1986): Effects of air humidity on the photosynthetic rate in the leaf of the rice plant. Jpn. J. Crop Sci., $55: 458^{-}$ 464.

Ishimara, K. and K. SAItoH (1987) : Diurnal courses of photosynthesis, transpiration, and diffusive conductance in the single-leaf of the rice plants grown in the paddy field under submerged condition. Jpn. J. Crop Sci., 56: 8-17.

IshiKaWA, S., T. OtKaWA and A. Furukawa (1990): Photosynthetic characteristics and water use efficiency of three coastal dune plants. Ecol. Res., $5: 377-391$.

Jones, M. B. (1987): The photosynthetic characteristics of papyrus in a tropical swamp. Oecologia, $71: 355-359$.

JoNes, M. B. (1988) : Photosynthetic responses of $C_{3}$ and $\mathrm{C}_{4}$ wetland species in a tropical swamp. $\mathrm{J}$. Ecol., 76 : 253-262.

Körner, Ch., J. A. Scheel and H. Bauer (1979): Maximum leaf diffusive conductance in vascular plants. Photosynthetica, $13: 45-82$.

Larcher, W. (1984): Ökologie der Pflanzen auf physiologischer Grundlage. Ulmer. Stuttgart. Madsen, T. V. and K. Sand-Jensen (1991): Photosynthetic carbon assimilation in aquatic macrophytes. Aquat. Bot., 41: 5-40.

McNaughton, S. J. (1973) : Comparative photosynthesis of Quebec and California ecotypes of Typha latifolia. Ecol., 54: 1260-1270.

ONDOK, J. P. and J. GLoser (1978) : Net photosynthesis and dark respiration in a stand Phragmites communis Trin. calculated by means of a model. II Results. Photosynthetica, 12 : 337343.

Pearcy, R. W., J. A. Berry and B. Bartholomew (1974) : Field photosynthetic performance and leaf temperatures of Phragmites communis under summer conditions in Death Valley, California. Photosynthetica, 8 : 104-108.

Roessler, P. G. and R. K. Monson (1985) : Midday depression in net photosynthesis and stomatal conductance in Yucca glauca. Oecologia, 67 : 380-387.

SALE, P. J. M. and P. T. ORR (1986): Gas exchanges of Typha orientalis Prest. communities in artificial ponds. Aquat. Bot., 23 : 329-339.

Sale, P. J. M., P. T. Orr, G. S. Shell and D. J. C. ERskine. (1985): photosynthesis and growth rates in Salvinia molesta and Eichhornia cras. sipes. J. Appl. Ecol., 22 : 125-137.

Spencer, W. and G. Bowes (1986): Photosynthesis and growth of water hyacinth under $\mathrm{CO}_{2}$ enrichment. Plant Physiol., 82 : 528-533.

Tenhunen, J. D., O. L. Lange, J. Gebel, W. Beyschlag and J. A. Weber (1984) : Changes in photosynthetic capacity, carboxylation efficiency, and $\mathrm{CO}_{2}$ compensation point associated with midday stomatal closure and midday depression of net $\mathrm{CO}_{2}$ exchange of leaves of Quercus suber. Planta, 162 : 193-203.

Tsuchiуa, T. (1991): Leaf life span of floatingleaved plants. Vegetatio, $97: 149-160$.

Tsuchiya, T., A. Shinozuka and I. Inusima (1993): Population dynamics, productivity and biomass allocation of Zizania latifolia in an aquatic-terrestrial ecotone. Ecol. Res., 8: 193- 198.

Westlake, D. F. (1982): The primary productivity of water plants. p. 165-180. In J. J. Symoens, S. S. Hooper and P. Compere (eds.), Studies on Aquatic Vascular Plants. Royal Bot. Soc. Belgium. Brussels, Otto Koeltz Sci. Publ., Koeningstein.

Yoshie, F. (1986) : Intercellular $\mathrm{CO}_{2}$ concentration and water-use efficiency of temperate plants 
with different life-forms and from microhabitats. Oecologia, 68: 370-374.

(著者: 土谷岳令- 筥塚篤, 千葉大学理学部生物学教 室, $\bar{\top} 263$ 千葉市稲毛区弥生町 1-33; 生嶋功, 千葉大 学理学部海洋生態系研究センター, テ 263 千葉市稲毛 区弥生町 1-33; Takayoshi TsuchiYA, Atsushi
Shinozuka, Department of Biology, Faculty of Science, Chiba University, 1-33 Yayoi-cho, Inage-ku, Chiba 263; Isao Ikusima, Marine Ecosystems Research Center, Faculty of Science, Chiba University, 1-33 Yayoi-cho, Inage-ku, Chiba 263)

Received : 8 August 1994

Accepted : 10 October 1994 